\title{
Impacts of Climate Change on Al Tadamon Locality's Livelihoods, Blue Nile State, Sudan
}

\author{
Maha Abd Elgaffar ${ }^{1, *}$, Abdelnabi M.S. ${ }^{2}$, Abdo G. $\mathbf{M}^{3}$ \\ ${ }^{1}$ Department of Environmental Studies, University of Medical Sciences and Technology (UMST), Sudan \\ ${ }^{2}$ Program Officer, International Fund for Agricultural Development (IFAD), Sudan \\ ${ }^{3}$ Water Research Center, University of Khartoum, Sudan
}

Copyright $\bigcirc 2018$ by authors, all rights reserved. Authors agree that this article remains permanently open access under the terms of the Creative Commons Attribution License 4.0 International License

\begin{abstract}
Climate change is a challenge in the Blue Nile State, Sudan. It puts pressure on the existing vulnerable natural resources and with population increase it leads to conflicts among pastorals and farmers communities. This cross sectional study aimed at determining the indicators of climate change and its impacts on the pastorals livelihoods. It also pointed out mitigation measures suggested by the communities to cope with the impacts of climate change. The methods used for data collection included review of meta-data, interviews based questionnaires and notes of researchers. The major findings indicated a decline in rainfall quantity (from $1000 \mathrm{~mm}$ to $800 \mathrm{~mm}$ ), duration (from 5 to 4 months/year) and patterns mostly during El Nino years. According to the respondents, animals died during the decades of severe droughts of 1992 to 2002. Pastorals used strategies to minimize the impacts of climate change such as performing small income generating activities in conjunction with herding.
\end{abstract}

Keywords Blue Nile State, Climate Change, Temperature Change, Rainfall Intensity, Pastorals Communities, Livelihoods and Mitigation Measures

\section{Introduction}

Climate scenario analyses conducted as part of the preparation of the First National Communications of Sudan indicated that average temperatures are expected to rise significantly. By 2060, projected warming in August will range from $1.5^{\circ} \mathrm{C}$ to $3.1^{\circ} \mathrm{C}$ and in January from $1.1^{\circ} \mathrm{C}$ to $2.1^{\circ} \mathrm{C}$. Projections of rainfall under climate change conditions also indicated significant deviations from baseline expectations. Findings from other models warned on average rainfall decreases of about $6 \mathrm{~mm} / \mathrm{month}$ in rainy seasons. The most vulnerable groups would be traditional rain fed farmers and pastorals [1].

Pastoralism in Sudan is a traditional way of life. It is impacted by climatic and environmental factors which lead to revisiting the use and management of natural resources.

The Blue Nile State is one of the eighteen states of Sudan. It has an area of $45,844 \mathrm{~km}^{2}$ and an estimated population of $1,108,391$ persons in 2018 as projected by Sudan Census Bureau of Statistics. The region hosts around forty different ethnic groups. The economic activity is based upon livestock and subsistence agriculture. It is a border State, sharing boundaries with Ethiopia and South Sudan; both neighboring countries have active war zones. Al Tadamon is one of the administrative units of the Blue Nile State (Figure. 1).

Geologically, the Blue Nile area is formed of basement complex, tertiary basalt rocks and recent deposits dominated by clays. Most of the basement rocks in the Blue Nile area is considered as a non- water bearing formation as reported by Whiteman in 1979 [2]

The Blue Nile basin, extends from Northwestern Ethiopian plateau towards the east and southern part of Sudan. It contains thick Mesozoic sedimentary section underlain by Neoproterozoic basement rocks and overlain by Oligocene and Quaternary volcanic rocks [3].

The vegetation cover of the Blue Nile State area was classified as desert vegetation, low wood land savannah and high land savannah [4]. El Tayeb, pointed out that large scale mechanized agriculture caused degradation in land, where the natural vegetation cover decreased due to illicit felling and charcoal making [5].

Reports [6] warned of climate change and the need to take advantage of opportunities to cope with the consequences. Improving land use and natural resources preservation including reduction of mechanized farming, forest protection and pasture land keeping were suggested in the national adaptation program of action [7].

It is indicated that the increase in the ratio of out-migration among the pastoral community members towards urban areas has reached up to $27 \%$ migrating in country and $11.9 \%$ migrating out of country to the Arab and other African neighboring countries [8]. 


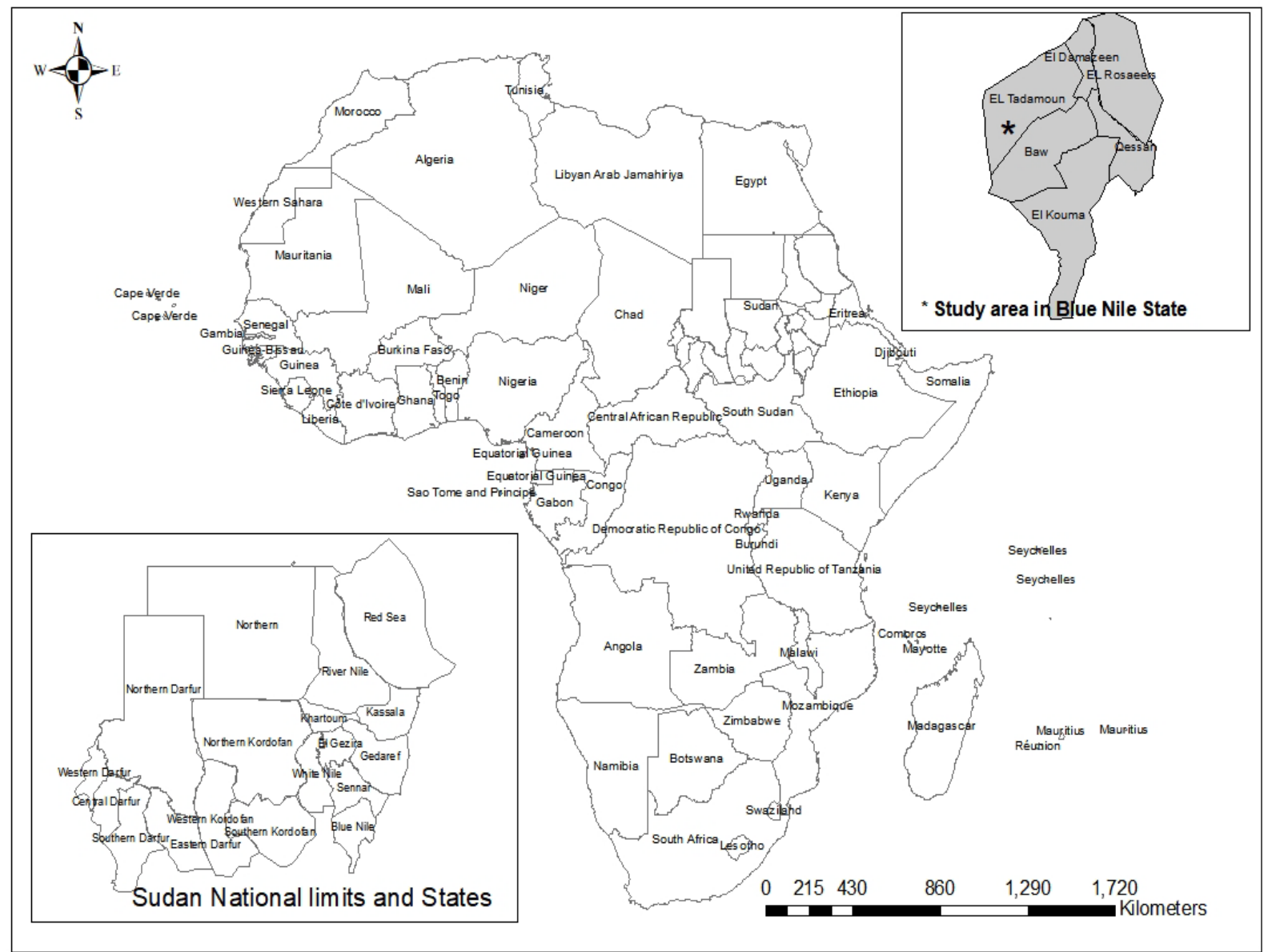

Figure 1. Location of $\mathrm{Al}$ Tadamon Locality in The Blue Nile State

Most of the vegetation at the area is formed of Shrub savannah, herbaceous crops and grass land (Figure2). The dominant trees are Acacia mellifera, Acacia nubica, Acacia seyal, Anogessus schimperi and Combertum harmanainum, [9].

Many small ephemeral streams are found in the area with a general flow direction, based upon the slope, towards the River Blue Nile or its tributaries. Ground water is found at depth ranging from 10 to 17 meters.

Rain falls from June to October when the annual rainfall exceeds $800 \mathrm{~mm}$. The average temperature ranges between $26^{\circ} \mathrm{C}$ in winter to $>38^{\circ} \mathrm{C}$ in summer [10] (. The hottest months of the year are April and May (Birch 2007).

In the Blue Nile State, climate is forecasted to become unpredictable with increase in temperatures, shifts in rainy seasons, and intense rain falls. Pastoralists of the State are being seriously affected by new environmental and social forces exacerbated by climate and geopolitical changes in the area (South Sudan Referendum of 2011). All of these contributed in restricting the movement of pastoralists towards alternative practices. Climate change is affecting pasture quality, water resources and rural landscape, in this respect, pastorals employ various coping strategies to deal with climate change and related stresses. Unfortunately, with the loss of their livestock and their livelihoods, they are more and more unable to adapt.

Various studies [10] focused on climate changes either through prediction or modelling with an attempt to develop strategies for reduction of disasters, however, the ecological impacts of climate change on communities and their coping strategies in Sudan remain to call the attention in this respect this research will try to fill some of these gaps. 


\section{Materials and Methods}

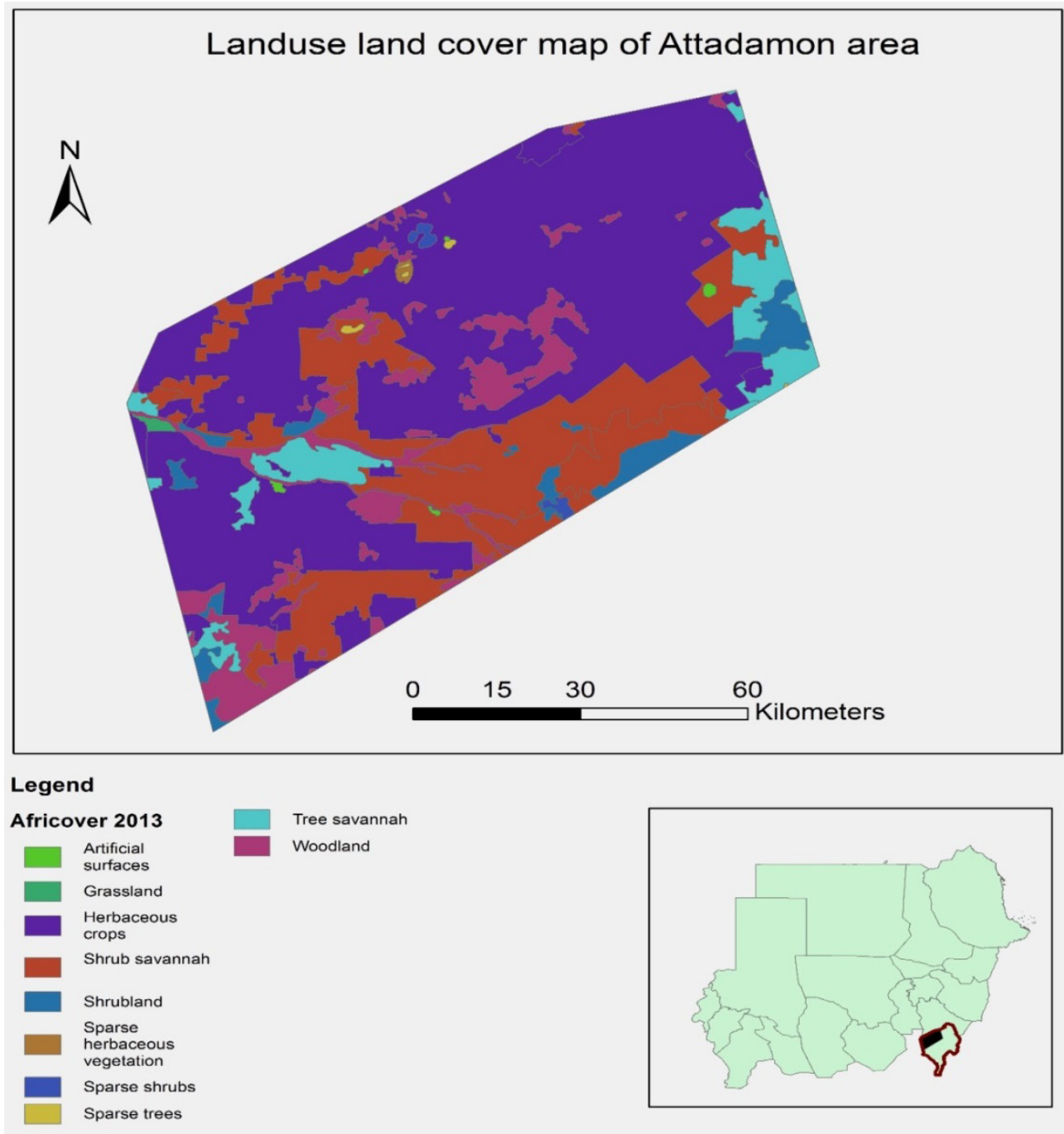

Figure 2. Land Use Map of Al Tadamon Locality

\section{Study Design:}

A field based cross sectional investigation was conducted in the period between January and March 2017. Primary data were collected through a standardized research tool developed and pre-tested by the researchers. Data collected were on awareness related climate change, and observations of researchers. In addition, focus group discussions enabled to collect data on mitigation measures adapted by households. Secondary data were readings of metadata obtained from the Meteorological station at Agadi- Al Tadamon locality, Blue Nile State for the period 1962 to 2016 (Agadi Meteorological station Reports 1962-2016).

\section{Study population:}

Al Tadamon area had an estimated population of 77,668 people as at 2017.This population comprised 45 ethnic groups.

\section{Sampling technique and Sample size:}

A convenient sampling technique was used. Seven villages were selected based on their accessibility. In each village, an average of 30 to 35 participants was selected after a well informed consent. In overall 250 respondents were included in the study. Seven focus discussions were organized with 11 participants per village.

\section{Data collection and analysis:}

Data collected from the household survey and focus discussions were summarized graphically (frequency tables and graphic). Whereas the meteorological data (rainfall and temperature) were summarized numerically (mean, standard deviation and median) and graphically frequency tables and graphics. 


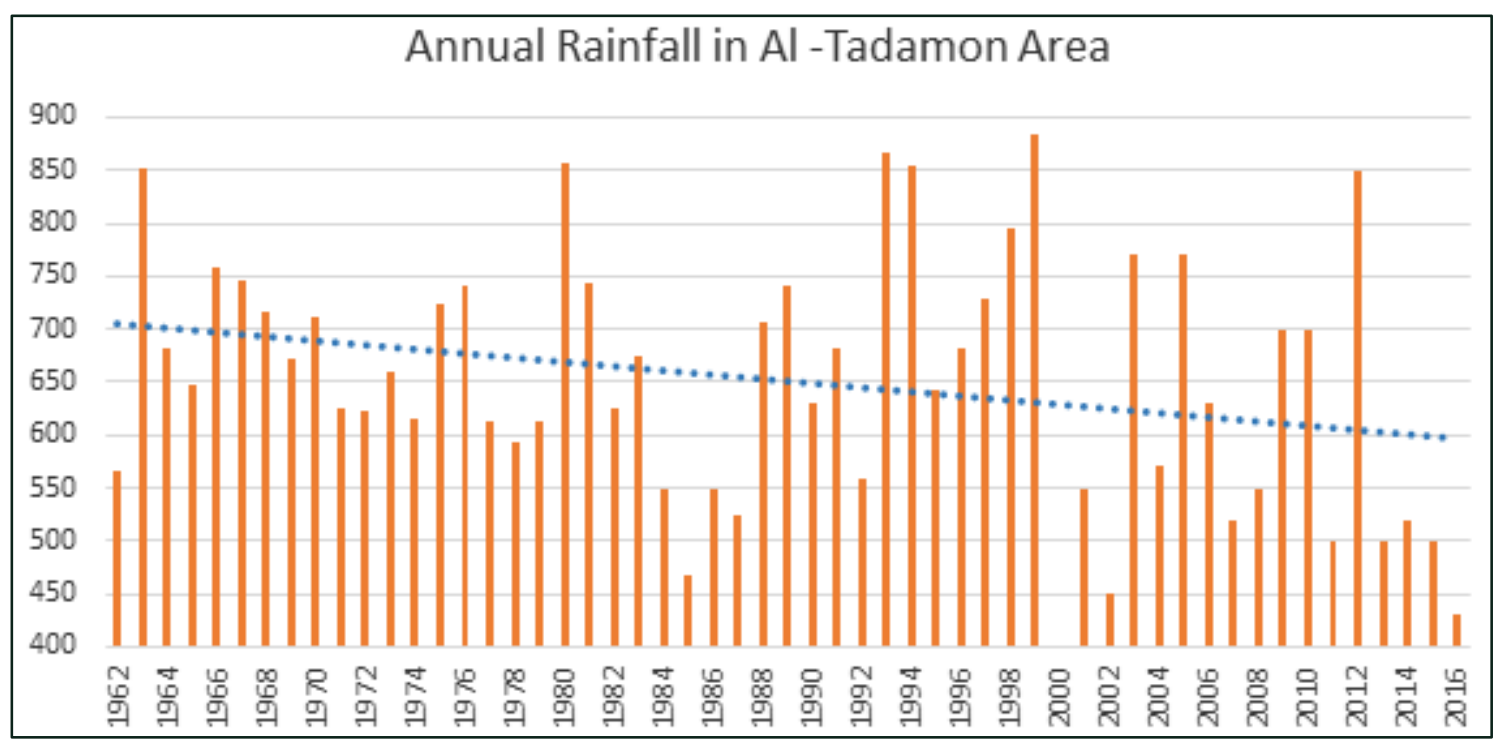

Figure 3. Annual Rainfall Al Tadamon Locality (source of data Agadi Meteorological Station Reports)

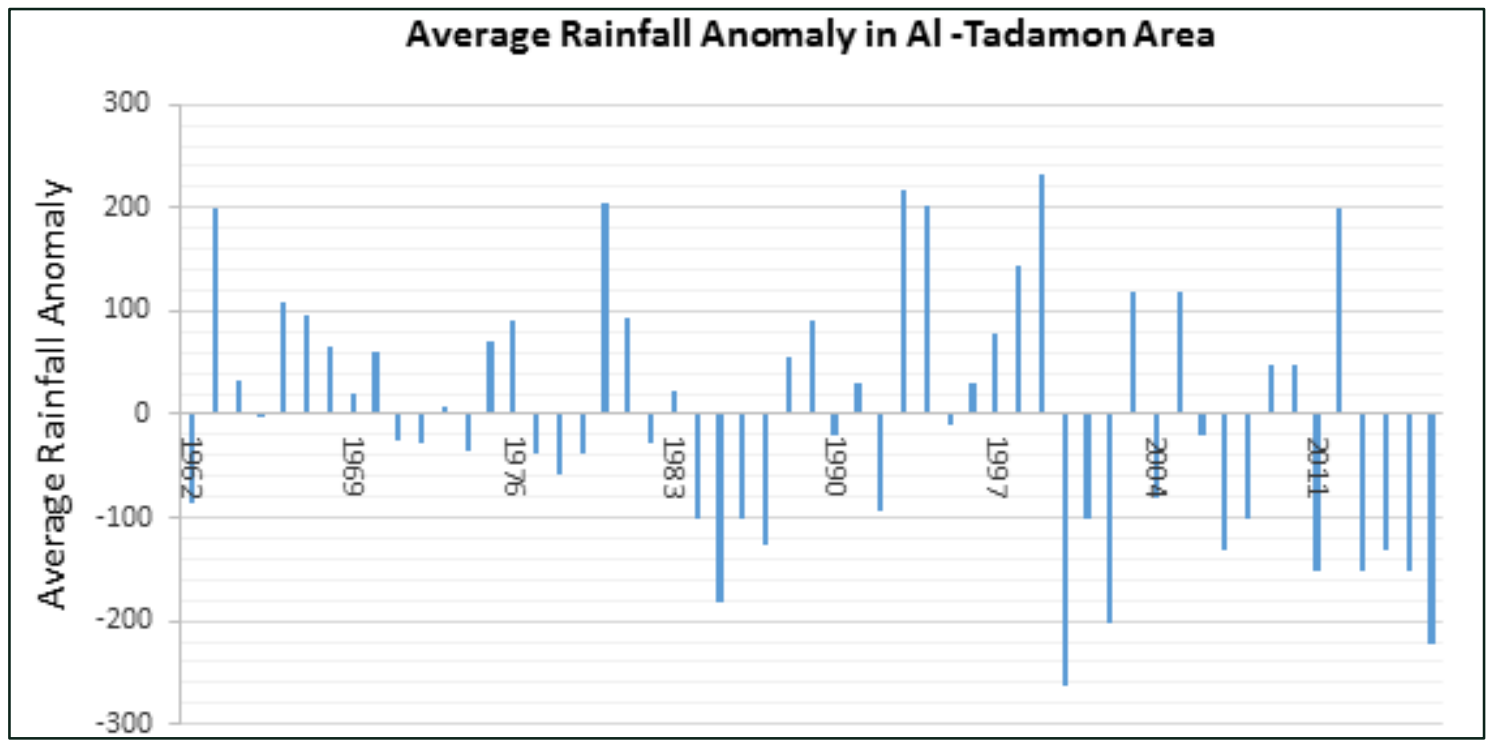

Figure 4. Average Rainfall Anomaly Al Tadamon Locality (After Agadi Meteorological Station Reports)

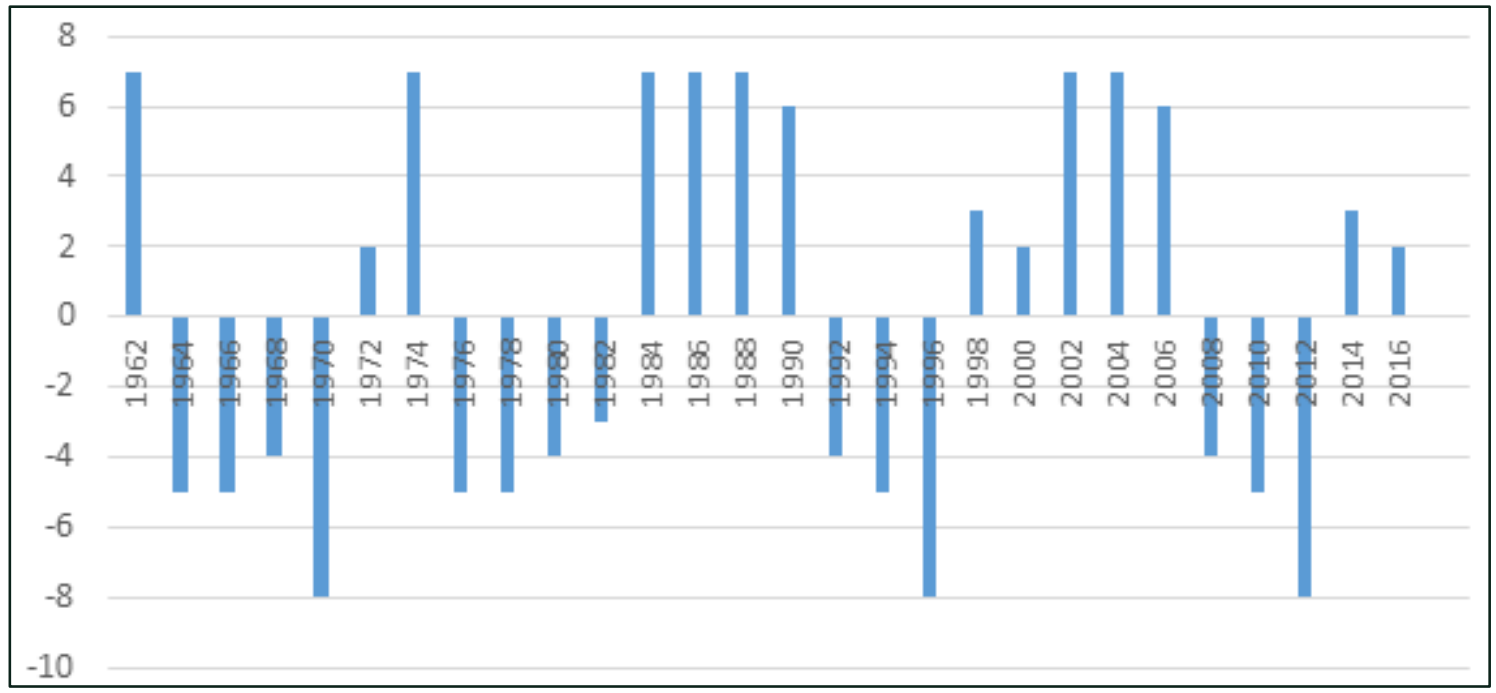

Figure 5. Average Temperature Degrees from 1962 to 2016 (Agadi Meteorological Station) 


\begin{tabular}{|c|c|c|c|c|c|c|}
\hline $2011-1962$ & $2000-2011$ & $2000-1991$ & $1990-1981$ & $1980-1971$ & $1970-1962$ & Month \\
\hline 49 & 47 & 78 & 38 & 41 & 40 & May \\
\hline 118 & 117 & 127 & 107 & 119 & 119 & June \\
\hline 177 & 160 & 168 & 190 & 187 & 181 & July \\
\hline 174 & 170 & 187 & 168 & 143 & 202 & August \\
\hline 131 & 135 & 141 & 102 & 149 & 129 & September \\
\hline 36 & 35 & 35 & 34 & 33 & 41 & October \\
\hline 685 & 664 & 737 & 689 & 672 & 712 & Total Annual \\
\hline
\end{tabular}

Figure 6. 10 Years Average Mean for Monthly Rainfall in mm, (Agadi Meteorological Station)

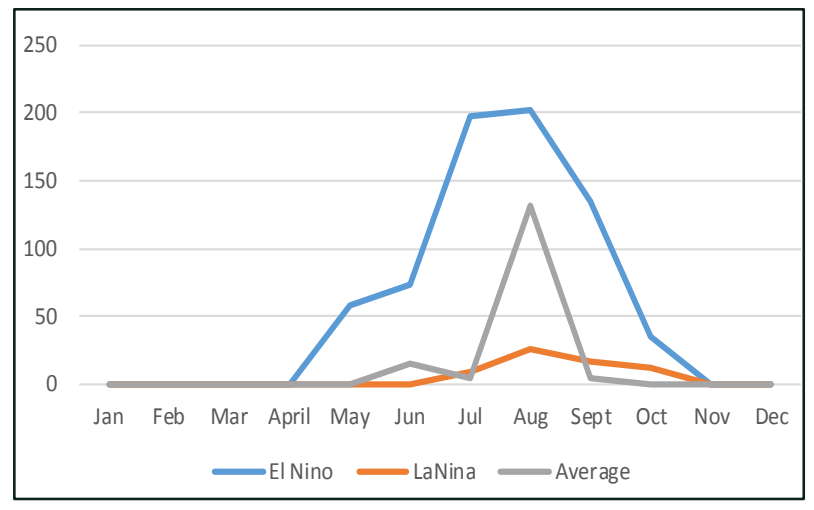

Figure 7. Monthly average Rainfall Behavior in El Nino Conditions of the years 2003, 2007, 2013, (Agadi Meteorological Station)

\section{Results}

In the Blue Nile State, the current major climatic hazards are consisted of drought and extreme flooding events. (Figure 5) indicated that average temperature degrees were expected to rise above normal mean. Moreover, there is an increase of the total rainfall intensity concentrated in mid-season month of August with a slight decrease in July and September (Figure 6). During El Nino, rainfall behavior changed with season peak shift from July to September. That was most often followed by an opposite behavior with rainfall duration and intensity decrease leading to a short wet season as illustrated by (Figure 7).

A sample of 250 participants was included in this survey. The contribution of females was very slim (Fig.8), as most of the participants were men as it was traditional that females do not speak to foreigners. The respondents age ranged between 20 to 50 years old (Fig.9), and mostly they were of very limited educational background (Fig.10)
The majority of the participants $(96 \%$, out of 100 samples) agreed on the effects of the climate change on their personal income as they depend on livestock and their products (Figure 11). About $96 \%$ of 100 respondents heard about climate change from the community radio as it represents the main source of information in the absence of electricity supply.

$85 \%$ of 77 focus group members left their home lands and migrated to the capital seeking better job opportunities as their original jobs are no longer supportive. $85 \%$ of the 77 focus group members mentioned that the economical reason represents the main pushing factor as $54 \%$ of them explained that cultivating crops are no longer on the top of their coping options (Fig.12). Only 55\% of the 100 respondents prefer to use mixed agriculture as a coping mechanism. $97 \%$ of 100 respondents think that climate change has affected their movement southwards and shortened it as the rainfall season is becoming shorter. $97 \%$ of 77 focus group members think that the provision of water sources and rehabilitation of rangelands presents the sustainable solutions to sustain their livelihoods (Fig.13), (Fig.14).

\section{Discussion}

This research was conducted in Al Tadamon Locality in the Blue Nile State. The study included a sample size of 250 respondents. Most of the participants were male of 20 to 50 years old and of an educational background of mostly illiterate with some of primary education. The collected data was limited due to time constraint and accessibility. Most of the pastorals communities are nomads therefore accessing them is possible only before the rainy season where they remain around the urban centers of the Blue Nile State. Rainfall data revealed a decrease beyond average during the rainy seasons 
indicating a significant annual variability since 1962 . Hence, rainfall became more variable in early and late periods of the wet season, therefore it is less reliable for agricultural activities. Temperatures are striking since 1980 s, with a warming of climate more pronounced during the night time than the day time [1]. From group discussions, the participants explained that there is a remarkable decrease in animal's products specially milk in addition to animal's number per household due to the deterioration in rangelands and scarcity of water sources for animal's drink as this was indicated by El Tayeb [5] and the Sudan's National Adaptation Program of Action [6]. According to the respondents animals died during severe droughts which occurred in 1992 and 2002 due La Nina [7]. The only known coping mechanism in the area was to do petty jobs in nearby towns or to migrate in nearby countries. Members of the pastoral communities migrated to the capital seeking for better job opportunities as the participants reported that economic reasons were the main factor pushing pastoralists to migrate [8]. On the other hand, climate change affects the seasonal movements of nomads; moving from northward during rainy season to escape from insects and diseases to southward in summer to fetch water for their animals [9]. Practicing of mixed agriculture, provision of water sources and rehabilitation of rangelands represent the urgent demanding inputs to avail food for animals and to sustain livestock and pastoralists livelihoods [10], [11].

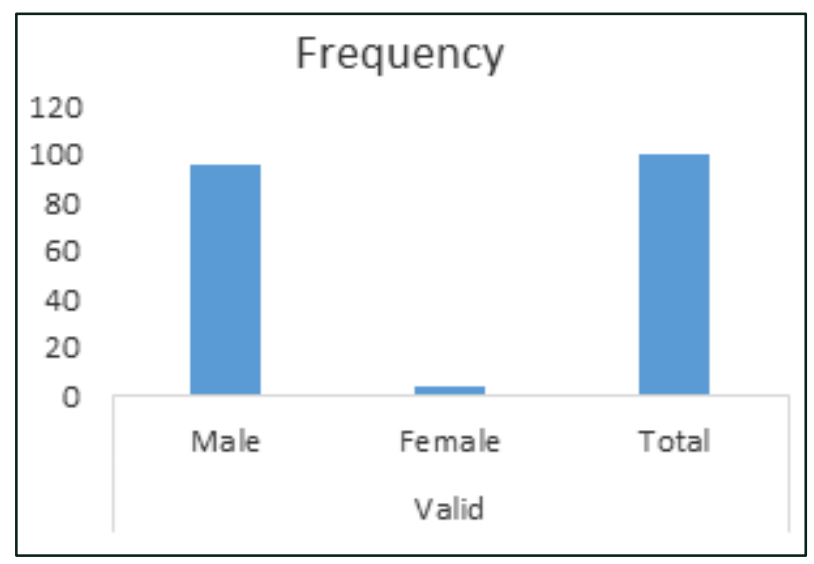

Figure 8. Gender of Respondents

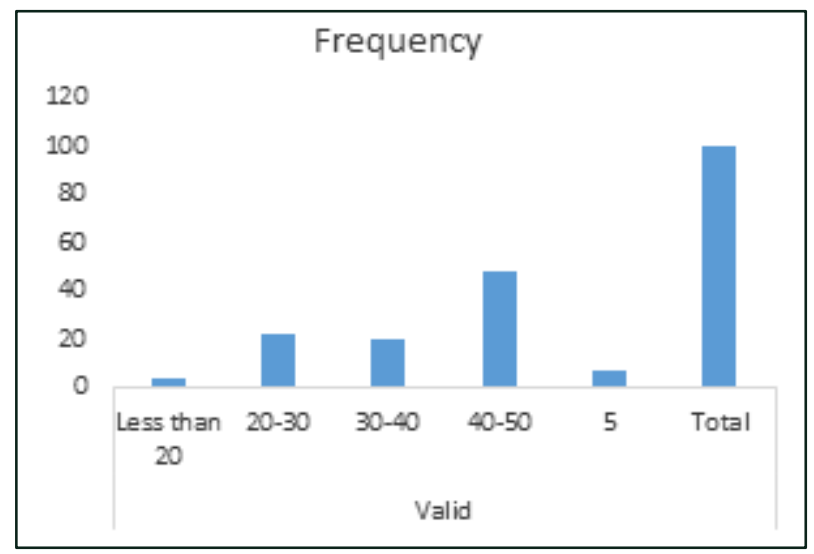

Figure 9. Age of Respondents

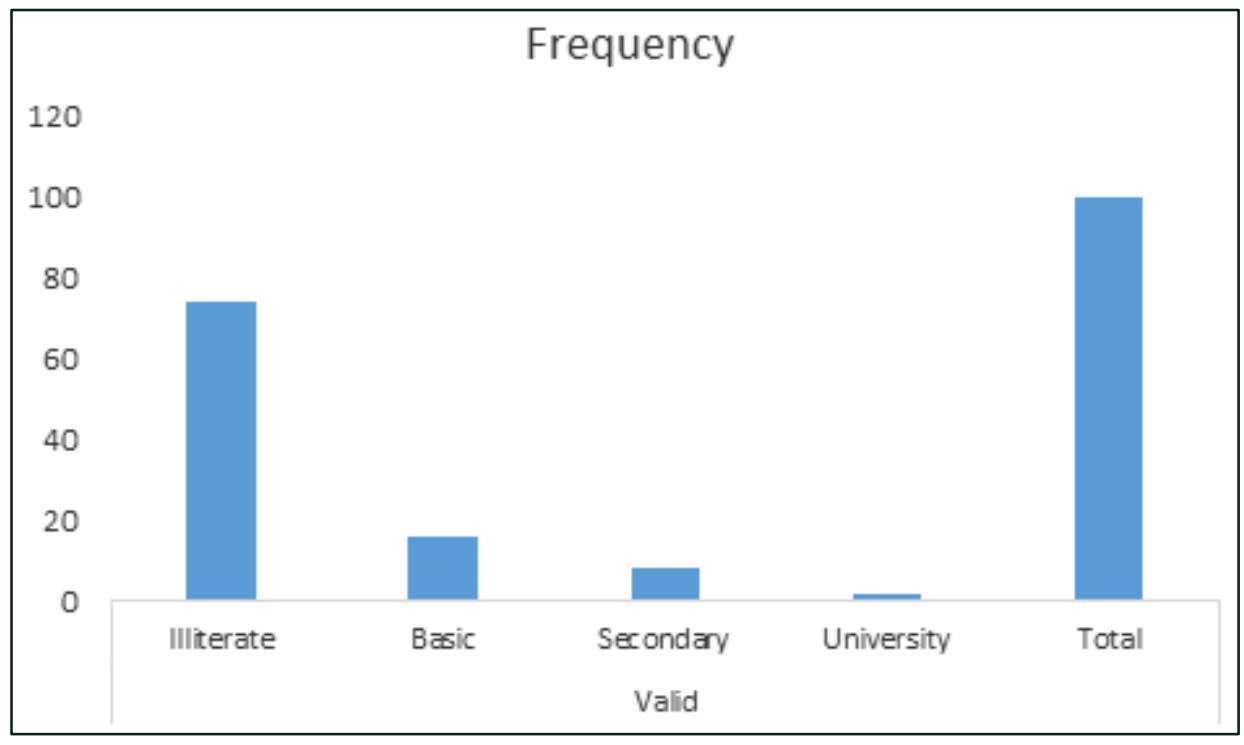

Figure 10. Respondent's Educational Background 


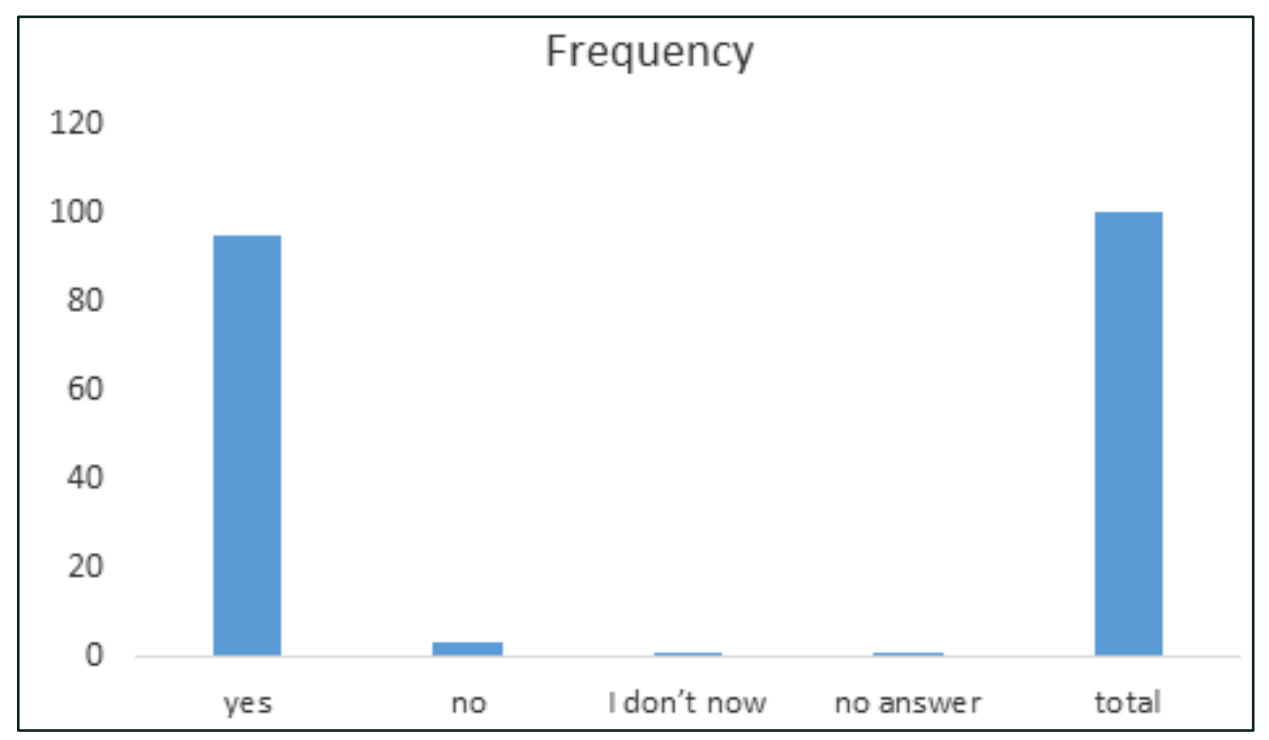

Figure 11. The number of respondents (out of 100 respondents) who's income is affected by climate change

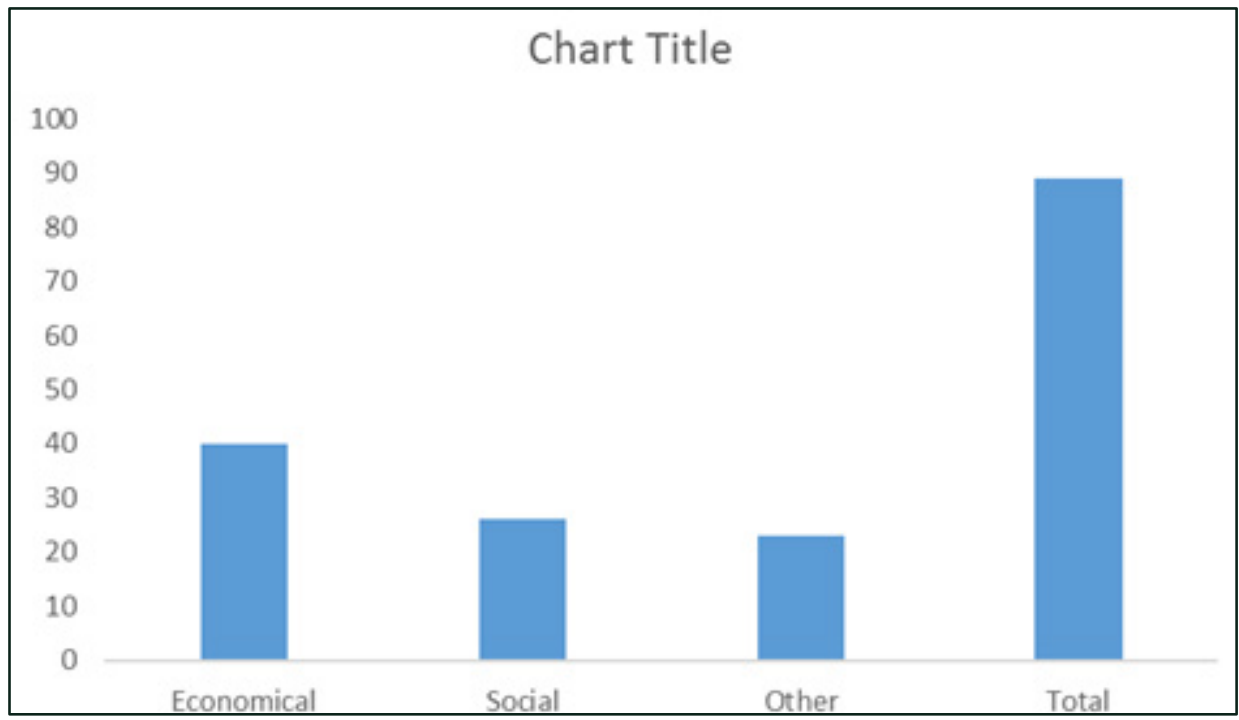

Figure 12. Climate Change Impacts on Households (among 100 respondents)

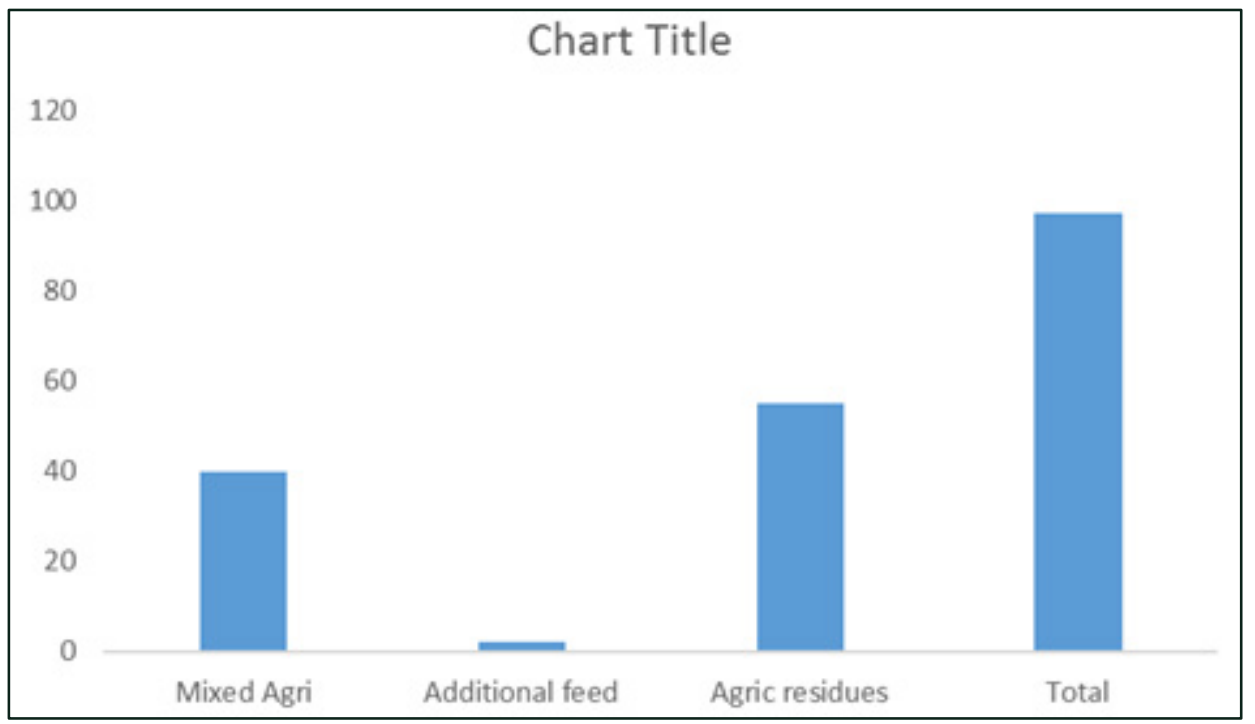

Figure 13. The suggested coping mechanism to adapt with climate change 


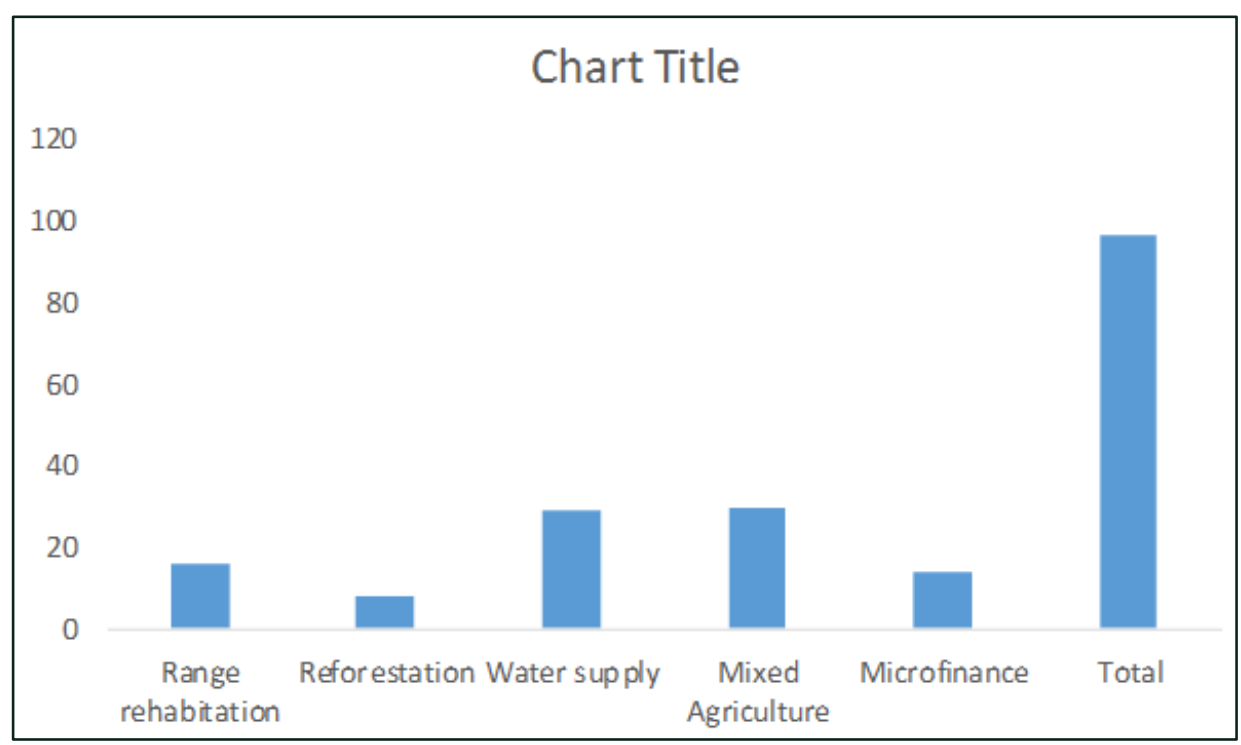

Figure 14. Options suggested by focus groups for sustainable pastoralism

\section{Conclusion and Recommendations}

The investigations regarding the impacts of climate change on the livelihoods of pastorals indicated that most of the respondents agreed on the negative effects on their personal income as they depend basically on livestock. For pastorals in Al Tadamon, the coping mechanism is to undertake petty jobs in near towns or migrate in nearby countries.

Pastorals expressed urgent needs for sustainable water resources, improved rangelands and better knowledge in mixed agricultural practices. It is important, therefore, to build pastorals capacities to adapt with climate change.

It would be more effective to enable and strengthen the inherent adaptive capacity of pastoralists as suggested by the focus groups to enable sustainability.

\section{REFERENCES}

[1] Balgis Osman Elasha, Nagmeldin Goutbi Elhassan, Hanafi Ahmed, and Sumaya Zakieldin, "Sustainable livelihood approach for assessing community resilience to climate change: case studies from Sudan" AIACC Working Paper No.17. August 2005.

[2] Whiteman, J. "The Geology of the Sudan Republic". London Clarendon Press: Oxford University Press, 1971. Volume 109 Issue 1.

[3] Gani, N.DS. Abdelsalam, M.G. Gera, S and Gani, M.R.
"Stratigraphic and structural evolution of the Blue Nile Basin, Northwestern Ethiopian Plateau", Geological Journal, 2009, Volume 44, Issue 1, January, Pages 30-56.

[4] Lebon, J. H. G. "Land Use in Sudan". World Land Use Survey Monograph. 1965.

[5] El Tayeb, G "Land Issues and Peace in Sudan", Sudan Environment Conservation Association, SECS and UNDP, Khartoum, 2011.

[6] IPCC. Climate Change: Impacts, Adaptation and Vulnerability. Contribution of Working Group II to the Third Assessment Report of the Intergovernmental Panel on Climate Change. Cambridge University Press. 2001

[7] NAPA, "National Adaptation Program of Action". Ministry of Environment and Physical Development, Republic of Sudan. Sudan, 2007.

[8] NAPA S. I. "Coping Mechanisms of Pastorals in Arid and Semi-Arid Regions in Sudan for the period 1970- 2008". $\mathrm{PhD}$, Unpublished Thesis, Geography Department, Khartoum University, 2009.

[9] Harrison, M. N. and Jackson, J. K. "Ecological Classification of the Sudan". Forest Department, Forest Bulletin No.2, 1958, Ministry of Agriculture, Khartoum. Sudan.

[10] HCENR (Higher Council for Environment and Natural Resources). National Adaptation Program of Action. 2007, Ministry of Environment and Physical Development, Republic of Sudan. Sudan.

[11] Elgizoli, I and Nimir, M. "Climate Change Adaptation and Decision Making in Sudan". SECS and OXFAM NOVIB, in collaboration with Gedaref University, Peace and Development Center. 2011. 